\title{
Effect and Mechanism of High-Pressure Processing: A Case Study of Flue-Cured Tobacco *
}

\author{
by \\ Chao Tan, Dongsheng Yang, Saibo Yu, Ke Li, Haifeng Tan, Hongmei Fan, Shitai Wang, \\ Qian Chen, Qi Liu, Yu Zhao, Xuemin Guo, Xinxin Jia, and Yong Jin
}

China Tobacco Hunan Industrial Co. Ltd., Changsha, Hunan, China

\section{SUMMARY}

After a high-pressure processing (HPP) treatment sensory evaluation of flue-cured tobacco showed modifications. There was no significant difference $(\mathrm{P}>0.05)$ between the routine chemical components (total sugar, reducing sugar, nicotine, and total nitrogen) of flue-cured tobacco after high-pressure processing treatment (HPP sample) and that of an untreated control group (CG). An overall judgement, which can be made from the observations of scanning electron microscopy (SEM), X-ray computed microtomography (micro-CT) and transmission electron microscopy (TEM), is that HPP could compress the inner tunnel and tissue gap in a flue-cured tobacco leaf. However, the ultrastructure, such as the cellular cytoskeleton, would not be changed. Compared with CG, the apparent density of the HPP sample rose by $19.3 \%$, while the true density only rose by $1.4 \%$. This also explained that the main effect of highpressure processing on flue-cured tobacco was microstructure compression rather than compression on the ultrastructure level. The differences between the lamina (leafshaped) sample, which were caused by high-pressure processing, were reflected in terahertz time-domain spectroscopy (THz-TDS), simultaneous thermal analysis (STA), and pyrolysis gas chromatography/mass spectrometry (Py-GC/MS). When the same tests were carried out using a sample that was milled to a powder, however, these differences were nearly removed. The milling process destroyed most of the microstructure of the flue-cured tobacco lamina; therefore, the results of THz-TDS, STA, and Py-GC/MS confirmed the hypothesis: That $400 \mathrm{MPa}$ high-pressure processing treatment minimally changes the ultrastructure of flue-cured tobacco and only changes its relatively larger microstructure. [Beitr. Tabakforsch. Int. 27 (2017) 168-181]

\section{KEY WORDS}

Mechanism, high pressure processing, THz-TDS, STA, Py-GC/MS

\section{ZUSAMMENFASSUNG}

Die sensorische Bewertung von heißluftgetrocknetem Tabak (Flue-cured-Tabak) war nach einer Behandlung mit Hochdruckverfahren (HPP) verändert. Es gab keinen signifikanten Unterschied $(\mathrm{p}>0,05)$ zwischen den chemischen Routinebestandteilen (Gesamtzucker, reduzierende Zucker, Nikotin und Gesamtstickstoff) von Flue-curedTabak nach Behandlung mit dem Hochdruckverfahren (HPP-Stichprobe) und denen einer unbehandelten Kontrollgruppe (CG). Eine Gesamteinschätzung, die aus den Erkenntnissen der Rasterelektronenmikroskopie (REM), Röntgen-Mikrotomographie (Mikro-CT) und Transmissionselektronenmikroskopie (TEM) gewonnen werden kann, ist, dass HPP den Raum im Innern von Leitbündeln und Geweben des heißluftgetrockneten Tabakblatts komprimieren könnte, die Ultrastruktur, wie das zelluläre Zytoskelett, dabei jedoch nicht verändert würde. Verglichen mit der Kontrollgruppe stieg die scheinbare Dichte der HPP-

* Received: $2^{\text {nd }}$ May 2017 - accepted: $7^{\text {th }}$ September 2017 
Probe um 19,3\%, während die tatsächliche Dichte nur um $1,4 \%$ zunahm. Damit erklärte sich auch, dass die Hauptwirkung des Hochdruckverfahrens auf Flue-cured-Tabak eine Kompression der Mikrostruktur und nicht der Ultrastruktur war. Die durch das Hochdruckverfahren verursachten Unterschiede zwischen der (blattförmigen) LaminaProbe spiegelten sich in den Untersuchungen mit TerahertzTime-Domain-Spektroskopie (THz-TDS), simultaner thermischer Analyse (STA) und Pyrolyse-Gaschromatographie/Massenspektrometrie (Py-GC/MS) wider. Als dieselben Tests an einer zu Pulver gemahlenen Probe durchgeführt wurden, waren diese Unterschiede jedoch fast verschwunden. Das Mahlverfahren zerstörte den Großteil der Mikrostruktur der Flue-cured-Tabak-Lamina. Somit haben die Ergebnisse der THz-TDS, STA und Py-GC/MS die Hypothese bestätigt, dass die Behandlung mit dem Hochdruckverfahren mit $400 \mathrm{MPa}$ nur die verhältnismäßig grobe Mikrostruktur veränderte, die Ultrastruktur von Flue-curedTabak dagegen nur minimal. [Beitr. Tabakforsch. Int. 27 (2017) 168-181]

\section{RESUME}

L'évaluation sensorielle du tabac séché à l'air chaud fut modifiée à la suite du traitement à ultra-haute pression (UHP). Aucune différence significative $(\mathrm{P}>0,05)$ ne fut observée entre les composants chimiques habituels (sucres totaux, sucres réducteurs, nicotine et azote total) du tabac séché à l'air chaud après le traitement à ultra-haute pression (échantillon UHP) et ceux du groupe témoin non traité (GT). D'une évaluation générale fondée sur les observations de la microscopie électronique à balayage (MEB), de la microtomographie aux rayons $\mathrm{X}$ assistée par ordinateur (micro-CT) et de la microscopie électronique à transmission (MET), il ressort que le traitement UHP pourrait resserrer l'espace entre les tissus et les conduits internes de la feuille de tabac séché à l'air chaud; toutefois, l'ultrastructure, telle que le cytosquelette des cellules, ne serait pas altérée. Comparativement au groupe témoin, la masse volumique apparente de l'échantillon UHP augmenta de $19,3 \%$ tandis que la masse volumique absolue n'augmenta que de 1,4\%. Ce constat expliqua aussi le fait que le principal effet du traitement à ultra-haute pression sur le tabac séché à l'air chaud fut une compression de la microstructure et non une altération au niveau de l'ultrastructure. Les différences entre les échantillons de parenchyme, causées par le traitement à ultra-haute pression, apparurent dans la spectroscopie $\mathrm{THz}$ dans le domaine temporel (THzTDS), l'analyse thermique simultanée (ATS) et la pyrolyse couplée à la chromatographie en phase gazeuse et spectrométrie de masse (Py-GC/MS). Cependant, lorsque les mêmes essais furent effectués à l'aide d'un échantillon broyé en poudre, ces différences disparurent presque totalement. Le processus de broyage avait détruit la majeure partie de la microstructure du parenchyme du tabac séché à l'air chaud; par conséquent, les résultats des essais par THz-TDS, par ATS et par Py-GC/MS confirmèrent l'hypothèse selon laquelle le traitement à ultra-haute pression $(400 \mathrm{MPa})$ altérait à peine l'ultrastructure du tabac séché à l'air chaud et ne modifiait que sa microstructure, dont la taille est relativement plus grande. [Beitr. Tabakforsch. Int. 27 (2017) 168-181]

\section{INTRODUCTION}

High-pressure processing (HPP), which utilizes water or another fluid as a pressure transmission medium, is a technology that is used for sterilization, enzyme inactivation, and physico-chemical property modification. As noted by DEFAYE et al. (1), the earliest record of an HPP study can be traced back to the $19^{\text {th }}$ century (2). The first commercial high-pressure food was produced in the 1990s in Japan (3). Recently, researchers have performed substantial research on this technology. Research into sterilization is particularly popular (4) and is used to extend the shelf life of foods (5), such as vegetables, fruit, meat, dairy, juice beverages, and more (6-10). There are several studies on high-pressure extraction and many reviews in this field as well (11-13).

Another main area of research is high-pressure modification. KHAN et al. improved the emulsifying behavior of sweet potato protein by high hydrostatic pressure (14). TIAN et al. placed wines under $550 \mathrm{MPa}$ for $30 \mathrm{~min}$, and after only 6 months, the treated wines had a volatile composition quality similar to that of untreated wines stored in pottery for 18 months (15). BOLUDA-AGUILAR et al. treated jasmine rice at $300 / 400 \mathrm{MPa}$, resulting in an instant rice with good sensory characteristics and good microbial stability (16). WENNBERG and NYMAN's study shows that it is possible to decrease the solubility of the dietary fiber in white cabbage with a high-pressure treatment (17). On the contrary, MATEOS-APARICIO et al. found that the ratio of soluble to insoluble dietary fiber increased with hydrostatic pressure and temperature for dry and hydrated okara samples (18). High-pressure-modified starch is frequently reported in the literature; however, the results are quite different: gluten-free bread shelf-life could be increased by using HPP-treated raw materials (19), an increase of gelatinization temperature under pressure occurred for both maize and rice starches (20). Improved baking properties and higher moisture retention capabilities, lower water activities, and slower hardening kinetics in bread were obtained by a high-pressure treatment (21).

High-pressure modification of food involves microstructure or chemical composition changes.

On the one hand, the change of microstructure is demonstrated by changes in viscosity, texture, consistency, suspension stability etc. The common cause of these changes is the activation or inactivation of biological enzymes (22). An enzyme is a type of protein, and the impact of high-pressure processing on its structure is shown by several aspects, for example, an unchanged primary structure with unfolding and disassociation of the secondary, tertiary, and quaternary structures (23), the exposure of interior hydrophobic and sulfhydryl groups (24), and the denaturation, aggregation, and gelation of protein molecules, as well as changes to their interfacial properties (25). On the other hand, a change in chemical composition will be reflected in an increase/decrease of flavor or color substances. Nevertheless, it is generally assumed that the fresh flavor of fruit and vegetables is not altered by highpressure processing since the structure of small molecular flavor compounds is not directly affected by high pressure unless, in an indirect way, the effects of pressure-induced enzymatic reactions and inactivation can lead to the alteration of flavor substances (26). KIM et al. proposed that 
a reduced garlic flavor can be obtained as a result of the inactivation of alliinase by an HPP treatment (500 MPa/13 min/pH9 and $500 \mathrm{MPa} / 15 \mathrm{~min} / \mathrm{pH} 6)$ (27). LIU et al. showed that after a $200 \mathrm{MPa} / 5 \mathrm{~min}$ treatment at room temperature, the enzyme activities of polyphenol oxidase (PPO) and peroxidase (POD) increased by $156.55 \%$ and $181.89 \%$, respectively. The activities of PPO and POD can influence the stability of anthocyanins, which form the color of petals and fruit (28). CHAKRABORTY et al. summarized the effect of HPP on the PPO and POD activities in apple juice, feijoa puree, kiwi fruit juice, peach juice, plum puree, songold plum puree, strawberries, tomato puree, and watermelon juice. Either the PPO or POD inactivation rate was in the range of $10-100 \%$. Therefore, the two enzymes were involved in the browning of fruit products (29).

Based on the unique modification ability of HPP, the scope of its research has been gradually expanded to a wider field, such as the treatment of flue-cured tobacco lamina. MAO et al. studied the influence of the moisture content on the sensory quality of flue-cured tobacco under HPP conditions (30). A speculation was put forward, but the paper lacked an in-depth study. Until now, similar literature is extremely scarce; therefore, the mechanism behind the HPP effect on flue-cured tobacco is not clear.

Flue-cured tobacco needs to be burned to assess its sensory quality. Combined with special characteristics, this paper proposes a new hypothesis for the mechanism of flue-cured tobacco HPP treatment, which was verified by a series of experiments.

\section{EXPERIMENTAL}

\section{Tobacco}

The flue-cured tobacco used for treatments was harvested from Dragon Mountain, Hunan Province, China. The samples were cured, redried and aged.

\section{High-pressure processing treatments}

High-pressure processing was performed with high-pressure equipment (model HHP.L1-600/3; Tianjin Huatai Senmiao Engineering and Technique Co. Ltd, Tianjin, China) and a hydraulic type cell with an inner capacity of $3 \mathrm{~L}$. A 100-g tobacco lamina sample was placed into a polyethylene plastic bag which was manually heat-sealed after being evacuated. Then, the bag with the sample in it was submitted to HPP at room temperature and $400 \mathrm{MPa}$ for $10 \mathrm{~min}$. Water was used as the pressure transmission medium. The pressure increase rate was approximately $220 \mathrm{MPa} / \mathrm{min}$, and pressure release was instantaneous. The treatment time in this study did not include the pressure increase and release time.

\section{Preparation of powder samples}

This paper involves four different forms of samples: an untreated control group of flue-cured tobacco in the form of lamina (CG-lamina), flue-cured tobacco in the form of lamina treated by HPP (HPP-lamina), an untreated control group of flue-cured tobacco in the form of a powder
(CG-powder), and flue-cured tobacco that was first treated by HPP and then milled to a powder (HPP-powder).

Portions of CG-lamina and HPP-lamina were taken to prepare CG-powder and HPP-powder. After drying at $40{ }^{\circ} \mathrm{C}$ for approximately $4 \mathrm{~h}$, the average water content of the lamina samples was about $5.8 \%$. The portions were milled to powder samples using a cyclone grinder (Cyclotec 1093 Sample Mill, Foss Tecator AB, Höganäs, Sweden).

\section{Sensory evaluation}

CG-lamina and HPP-lamina were used to produce an unblended cigarette with a cigarette length of $84 \mathrm{~mm}$, a filter length of $25 \mathrm{~mm}$, and a circumference of $24 \mathrm{~mm}$. The unblended cigarette was allowed to equilibrate for $48 \mathrm{~h}$ at a constant temperature and humidity, where the temperature was $22 \pm 2{ }^{\circ} \mathrm{C}$ and the humidity was $60 \%+5 \%$. The sensory evaluation of the unblended cigarette was in accordance with the standard method (31); the maximum score scale was 9 .

The sensory evaluation included the aroma characteristics (aroma quality, aroma quantity, and offensive odor), smoke characteristics (physiological strength and concentration) and taste characteristics (irritancy, aftertaste and sweetness). The direction of change and extent of sensory quality were reflected in the score directly.

\section{Routine chemical component measurement}

The reducing and total sugars, nicotine, and total nitrogen were determined by colorimetric methods with a continuous flow automatic chemical analyzer (Auto Analyzer 3, SEAL Analytical GmbH, Norderstedt, Germany). The reducing and total sugars were extracted in a $5 \%$ acetic acid solution. After reacting with $p$-hydroxybenzoic acid hydrazide, the reducing and total sugars were analyzed by the formation of a yellow azo compound (32). Nicotine was extracted in water and determined after a reaction with on-line-generated cyanogen chloride and sulfanilic acid (33). Total nitrogen was quantified as ammonia by the Berthelot reaction after the Kjeldahl digestion of CGpowder and HPP-powder; ammonia reacts with sodium salicylate in the presence of hypochlorite to form a blue indophenol (34). Three repeated experiments were performed with each lamina and powder sample. The data was analyzed using SPSS 16.0 software (SPSS Inc. Chicago, IL, USA). Student's t-test at a level of 0.05 was performed for routine chemical component analysis to determine the significance of the changes before and after HPP.

\section{Morphology detection}

The microstructures of CG-lamina and HPP-lamina were observed by scanning electron microscopy (SEM) (Hitachi-S3400N, Hitachi High-Technologies Corporation, Tokyo, Japan). After sputtering platinum (Pt) on the tested samples' surface for $30 \mathrm{~s}$, according to standard SEM operation procedures, the samples were placed into the SEM vacuum chamber for magnified observations.

The high-resolution industrial CT scanner used in this research was an X-ray computed microtomography (micro-CT) system (phoenix nanotom ${ }^{\circledR} \mathrm{m}, \mathrm{GE}$ Sensing \& Inspection Technologies, Wunstorf, Germany) in high- 
resolution mode, which was qualified for sample sizes of $0.25 \mathrm{~mm}$ to $250 \mathrm{~mm}$.

The ultrastructure of the samples was investigated by transmission electron microscopy (TEM) (JEM-1200EX, JEOL, Tokyo, Japan). Small portions of CG-lamina and HPP-lamina were initially fixed in $2.5 \%$ glutaraldehyde at $4{ }^{\circ} \mathrm{C}$ and then rinsed in phosphate buffered saline three times, 10 min each time. The buffer was then replaced with $30 \%, 50 \%, 70 \%, 90 \%$ ethanol, and two replications of $100 \%$ ethanol for $10 \mathrm{~min}$ each. The samples were embedded in EPON 812 epoxy resin and solidified in an incubator at $37^{\circ} \mathrm{C}, 45^{\circ} \mathrm{C}$, and $65^{\circ} \mathrm{C}$ for $24 \mathrm{~h}$ each. The semi-thin and ultra-thin sections were cut with an UltracutE microtome (Reichert-Jung, Vienna, Austria). Finally, they were stained by uranyl acetate lead nitrate.

\section{Density and inner pore volume}

The true density was measured using an automatic density analyzer (Ultrapyc 1200e, Quantachrome Instruments, Boynton Beach, FL, USA), and it was calculated as the average value of three individual measurements. For the measuring method for the apparent density, refer to (35). The equation for calculating the volume of the inner pore is

$\mathrm{V}_{\mathrm{g}}=1 / \rho_{\mathrm{a}}-1 / \rho_{\mathrm{t}}$

where $V_{g}$ is the inner pore volume $\left(\mathrm{cm}^{3} / \mathrm{g}\right), \rho_{\mathrm{a}}$ is the apparent density $\left(\mathrm{g} / \mathrm{cm}^{3}\right)$, and $\rho_{\mathrm{t}}$ is the true density $\left(\mathrm{g} / \mathrm{cm}^{3}\right)$.

\section{Terahertz time-domain spectroscopy (THz-TDS) analysis}

The powder sample for THz-TDS analysis was a round wafer with a $19 \pm 1 \mathrm{~mm}$ diameter and a $2.7 \pm 0.1 \mathrm{~mm}$ thickness, which was formed by using a tablet press machine. The lamina sample was cut to a $12 \mathrm{~mm} \times 12 \mathrm{~mm}$ square for THz-TDS analysis.

For our THz-TDS equipment, a mode-locked Ti:sapphire laser with a central wavelength of $780 \mathrm{~nm}$ and a pulse duration of less than 100 femtoseconds was equipped. In the THz-TDS measurements, the temporal signals were collected by a detector, while the amplitude spectrum and phase spectrum were obtained by the method of windowed Fourier transformation. By comparing the sample signal and a reference signal, the dielectric properties of materials, such as the complex refractive index, were easily obtained.

\section{Simultaneous thermal analysis (STA)}

Simultaneous thermal analysis (STA) was performed to evaluate the thermal degradation of HPP-lamina, CG-lamina, HPP-powder and CG-powder. The HPP-lamina or CG-lamina samples for simultaneous thermal analyses were cut into small square pieces of approximately $3 \mathrm{~mm} \times 3 \mathrm{~mm}$. The mass of a small piece of sample was $2 \pm 0.1 \mathrm{mg}$ for each run of the measurement. The samples were analyzed at a heating rate $15{ }^{\circ} \mathrm{C} / \mathrm{min}$ from room temperature to $700{ }^{\circ} \mathrm{C}$ in an atmosphere of air flowing at $20 \mathrm{~mL} / \mathrm{min}$. Both weight loss and heat flow profiles were obtained during combustion until the sample was burned out. The equipment used was a simultaneous thermal analyzer (STA 449 F3 Jupiter, Netzsch, Selb, Germany).

\section{$P y-G C / M S$ analysis}

Py-GC/MS analyses were carried out using a Pyroprobe 5000 Series pyrolyzer (Model 5200, CDS Analytical, Inc. Oxford, PA, USA) connected to a GC/MS (Agilent 7890A GC System coupled with an Agilent 5975C inert XL MSD mass spectrometer). The HPP-lamina or CG-lamina samples for Py-GC/MS were cut into stripe shapes with a size of $13.5 \mathrm{~m} \times 1 \mathrm{~mm}$ (mass $0.001 \mathrm{~g} \pm 0.0005 \mathrm{~g}$ ).

The stripe shaped sample was placed in a $25 \mathrm{~mm} \times \varphi 2 \mathrm{~mm}$ cylindrical quartz tube. A suitable size of glass wool was fitted on both ends of the quartz tube, which was loaded with sample. The quartz tube was placed in a platinum coil at room temperature and was then inserted into the pyrolysis chamber. The pyrolyzer interface was heated from $50^{\circ} \mathrm{C}$ to $250{ }^{\circ} \mathrm{C}$ at $100{ }^{\circ} \mathrm{C} \mathrm{min}{ }^{-1}$ and held at $250{ }^{\circ} \mathrm{C}$ for $1 \mathrm{~min}$. The initial temperature of the pyrolyzer was maintained at $50{ }^{\circ} \mathrm{C}$ for $20 \mathrm{~s}$, then heated at $10^{\circ} \mathrm{C} / \mathrm{ms}$ to $800^{\circ} \mathrm{C}$, and held at this temperature for $20 \mathrm{~s}$. The volatiles were trapped on a TENAX adsorbent trap before being desorbed at $280^{\circ} \mathrm{C}$ onto a heated transfer line that was held at $250{ }^{\circ} \mathrm{C}$. The purge flow of helium to remove any oxygen from the sample, prior to pyrolysis, was $25 \mathrm{~mL} / \mathrm{min}$.

The heated transfer line was connected to the injector of the $\mathrm{GC}$ inlet port, which was set to $250^{\circ} \mathrm{C}$. The split ratio was set to 200:1. The pyrolysis products were separated on a capillary column (Agilent HP INNOWAX; $60 \mathrm{~m} \times 0.25 \mathrm{~mm}$ i.d., $0.25 \mu \mathrm{m}$ film thickness) using helium as the carrier gas at a $1.0 \mathrm{~mL} / \mathrm{min}$ constant flow. The $\mathrm{GC}$ oven temperature program was $50{ }^{\circ} \mathrm{C}$ (held for $1 \mathrm{~min}$ ) at $2{ }^{\circ} \mathrm{C} / \mathrm{min}$ to $150{ }^{\circ} \mathrm{C}$ (held for $15 \mathrm{~min}$ ) and then ramped to $230{ }^{\circ} \mathrm{C}\left(2{ }^{\circ} \mathrm{C} / \mathrm{min}\right.$, held for $1 \mathrm{~min}$ ). The mass spectra were obtained by electron ionization at $70 \mathrm{eV}$ and an $\mathrm{m} / \mathrm{z}$ scan from 33 to 500 .

\section{RESULTS AND DISCUSSION}

\section{Sensory evaluation}

Table 1 presents the mean values of the samples before and after the HPP treatment. The sensory qualities of the HPP sample cigarette which improved were the aroma quality, offensive odor, irritancy, aftertaste, and sweetness; however, the physiological strength and concentration decreased. At first, the probable cause was considered to be that the HPP treatment had changed the composition of the fluecured tobacco. To verify whether this was correct or not, it was necessary to determine the routine chemical components.

Table 1. The sensory evaluation of the samples before and after HPP treatment.

\begin{tabular}{lccc}
\hline Sample & CG cigarette & HPP sample cigarette \\
\hline Aroma quality & 5.5 & 5.7 \\
Aroma quantity & 6.5 & 6.5 \\
Offensive odor & 5 & 5.5 \\
Physiological & 7.5 & 7.2 \\
$\quad$ strength & 7.5 & 7.1 \\
Concentration & 6 & 6.1 \\
Irritancy & 5 & 5.2 \\
Aftertaste & 4 & 4.2 \\
Sweetness & & \\
\hline
\end{tabular}


Table 2. Routine chemical components of CG and HPP sample.

\begin{tabular}{ll|c|c|c|c}
\hline Samples & & Total sugar (\%) & Reducing sugar (\%) & Nicotine (\%) & Total nitrogen (\%) \\
\hline CG & Parallel 1 & 14.97 & 12.27 & 3.74 & 2.67 \\
& Parallel 2 & 15.00 & 12.26 & 3.80 & 2.77 \\
& Parallel 3 & 15.00 & 12.20 & 3.84 & 2.63 \\
HPP sample & Parallel 1 & 15.04 & 12.22 & 3.76 & 2.62 \\
& Parallel 2 & 15.40 & 12.62 & 3.77 & 2.63 \\
& Parallel 3 & 15.51 & 12.50 & 3.70 & 2.65 \\
\hline
\end{tabular}

\section{Routine chemical components}

Table 2 contains the routine chemical components of the samples before and after the HPP treatment. Three parallel tests for each sample were performed. As can be seen from the table, the changes in the content of the routine chemical composition are very small. The data in Table 2 was analyzed by SPSS, and there was no significant difference between the CG and HPP samples $(\mathrm{P}>0.05)$. The HPP was carried out at room temperature, and this process neither introduced a new substance nor eliminated an original substance. Thus, the changes could only be due to the transformation of an original substance in the tobacco lamina. It was reported in the literature that HPP at room temperature only disrupts relatively weak chemical bonds, such as hydrogen bonds, hydrophobic bonds, and ionic bonds (36). Covalent bonds are not affected. The sensory evaluation of the samples before and after the HPP treat- ment was different, this fact was demonstrated by the previous experiment. However, relatively large changes cannot be seen in Table 2. This shows that the influence of the composition change on the sensory evaluation in this study is limited. The contribution of microstructure changes to the sensory evaluation difference should be dominant.

\section{Morphology observation}

In Figure 1, we show top-down views of representative SEM images at low and high magnifications. As illustrated in Figures $1 \mathrm{~A}$ and $1 \mathrm{C}$, several stomata distributed on the CG's surface are clearly visible. At least 20 stomata in the range of one square millimeter can be seen. It is difficult to find stomata in the SEM image of the HPP sample's surface (Fig. 1B). However, it can be found that stomata exist in the high-magnification SEM image, with the stomatal openings completely closed (Figure 1D).
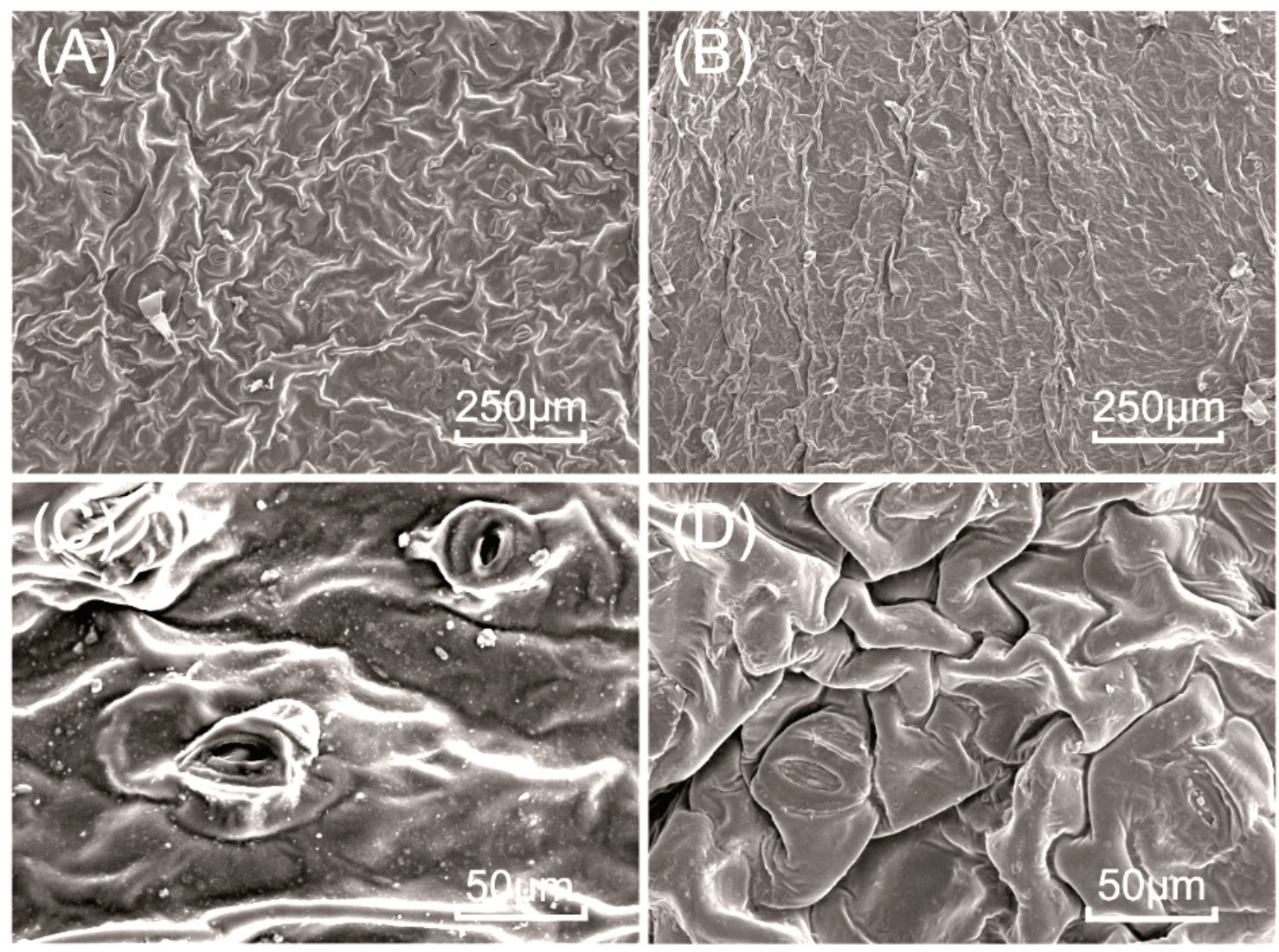

Figure 1. SEM top-view images of the samples (A) CG (100x); (B) HPP (100x); (C) CG (500x); (D) HPP (500x). 

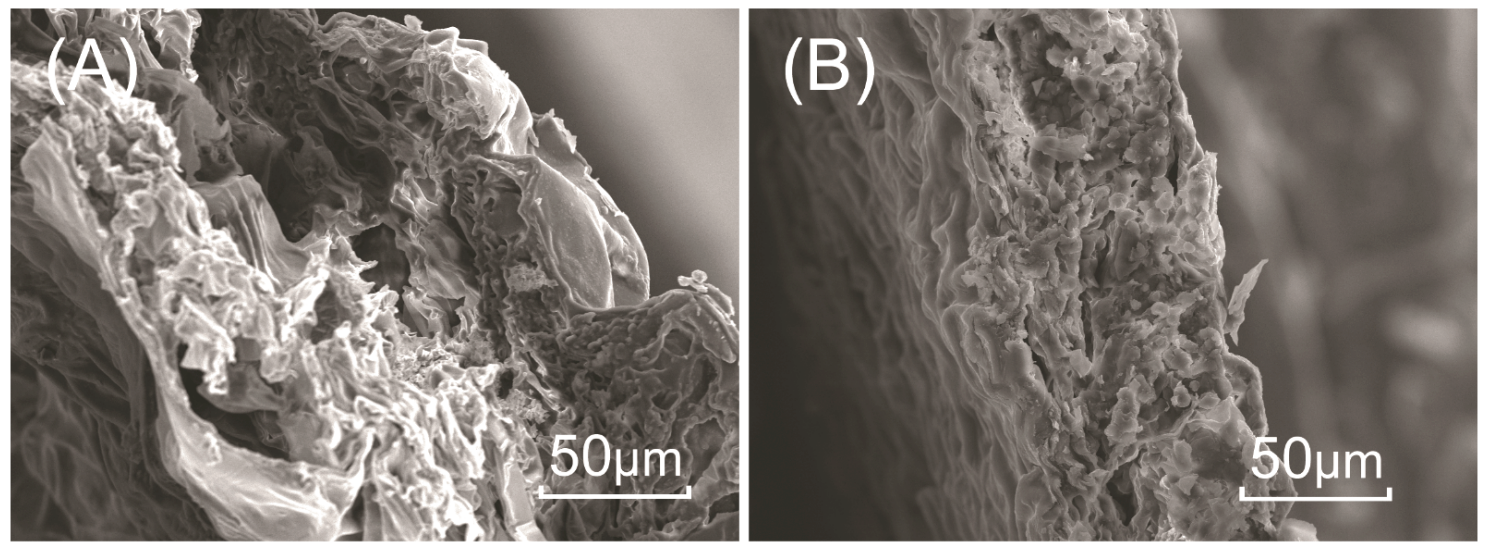

Figure 2. SEM cross-sectional images of the samples (A) CG and (B) HPP.

They can barely be visually identified because they are integrated with the adjacent tissue. Stomatal apertures are modulated by light signals, water status, $\mathrm{CO}_{2}$, temperature, and other environmental conditions (37-39). MELOTTO et al. reported that plant and human pathogenic bacteria induced stomatal closure (38). However, these research objects were living plants that could regulate the opening and closing of stomata autonomically, while the tobacco lamina sample in our experiment was no longer alive. It had experienced several processing steps curing, redrying, and aging. Thus, the SEM result shows that the phenomenon of stomatal closure in Figure 1D was caused by high pressure. In addition, high pressure also makes the tobacco lamina shrink and leads to several wrinkles on its surface.

When comparing the cross-sectional view of the samples

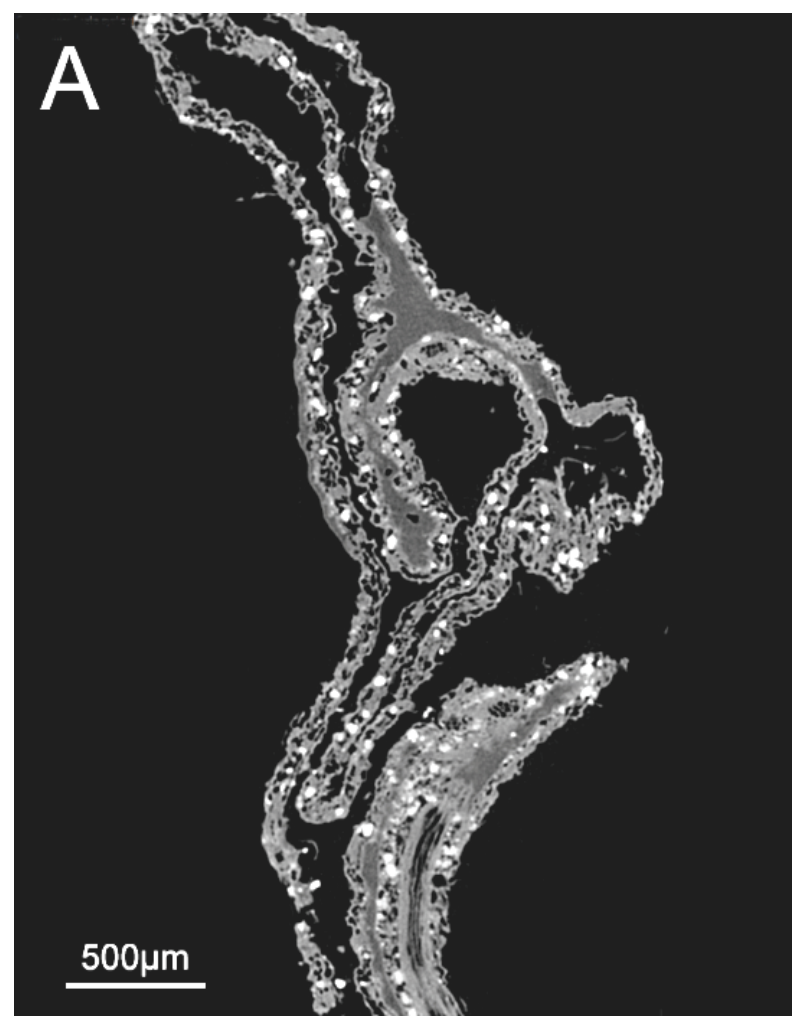

before and after the HPP treatment (Figures 2A and 2B), the collapse of some tunnel openings can be found. Others were compressed by the high pressure. Furthermore, the HPP sample became substantially thinner, and the mesophyll tissue gap decreased.

To observe the deep internal changes, a micro-CT imaging system was used to view the CG and HPP samples. Micro-CT, which is nondestructive, can provide qualitative information about structure in 3D. In addition, samples can be virtually sectioned in any plane to study the spatial relationships of the internal structures (40). Figure 3 shows the micro-CT images of the CG and HPP samples. Compared with $\mathrm{CG}$, the internal channel of the HPP sample was narrow, the surface hole opening was compressed, and the gap within the mesophyll tissue was decreased.

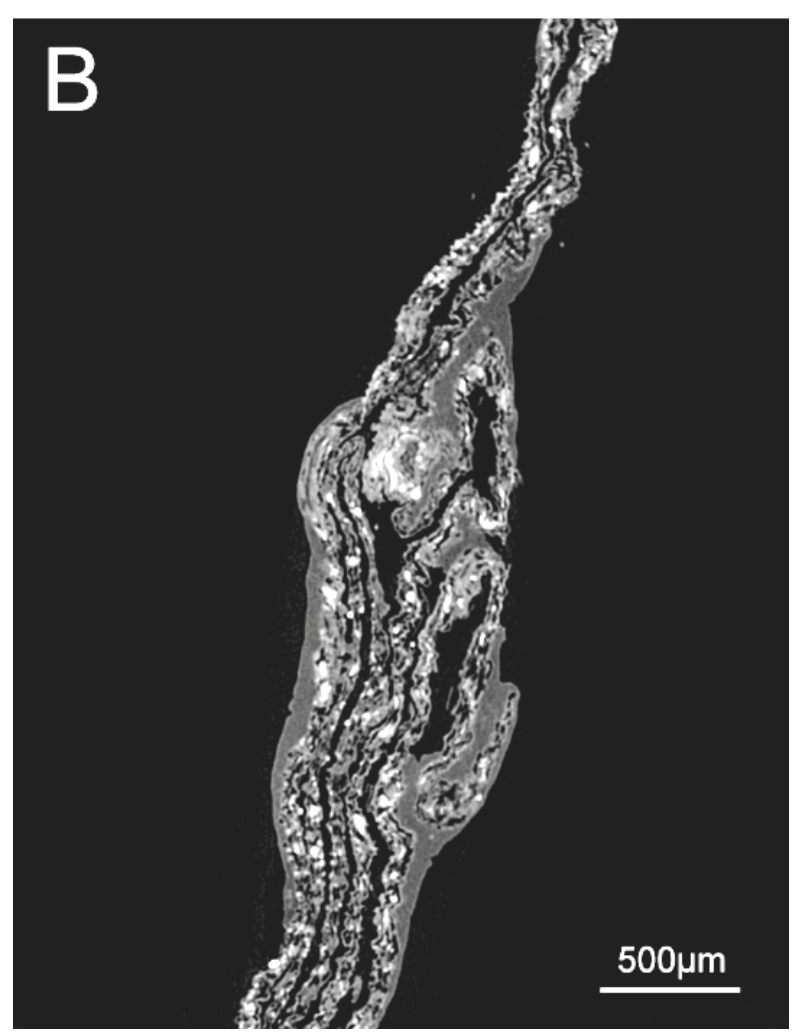

Figure 3. Micro-CT images of the samples (A) CG and (B) HPP. 
Especially for some of the larger hole areas, their volumes were significantly reduced. KUROKI et al. used micro-CT with fresh cucumber, and the black and white region in the micro-CT image could distinguish gas and liquid in the cucumber tissue. The shape of the black region is irregular, which suggests that there is an air gap between cells rather than a bubble in the cell (41). These air gaps are not fully connected, which means that HPP is probably able to damage certain specific regions. However, our samples were not fresh tobacco leaves and their water content was very low. Therefore, KUROKI's method could not be used in our samples to determine the amount of air gaps.

The results from SEM and micro-CT could not determine whether the ultrastructure, which is smaller than the microstructure, of our sample was changed. The ultrastructure of the sample was studied by TEM. The cell wall boundary could be seen clearly from the $6000 \times$ magnification TEM images (Figures 4A and 4B). The cell nucleus, vacuoles and other organelles could not be observed because they collapsed during the curing and redrying processes. The intracellular substances that were observed were black osmiophilic granules and a small amount of incompletely degraded starch granules. The mature lamina structure was loose, and the gap between its cells was relatively large. The gap was further increased when an abundance of water was lost during the curing and redrying processes. As seen by comparing Figures $4 \mathrm{~A}$ and $4 \mathrm{~B}$, the gaps of the CG and HPP samples did not show significant differences, which means that the gap did not collapse under a pressure of $400 \mathrm{MPa}$. As illustrated in the high-magnification TEM image (Figures 4C and 4D), the skeleton structure of the HPP sample was kept intact and the deformation of the ultrastructure was not clear. It can be concluded that it is difficult for $400 \mathrm{MPa}$ HPP to change the ultrastructure of flue-cured tobacco lamina.

\section{Density and inner pore volume}

Table 3 shows the densities and inner pore volumes of the CG and HPP samples. As shown in Table 3, compared with CG, the apparent density of the HPP sample increased by $19.3 \%$ (from 0.942 to $1.124 \mathrm{~g} / \mathrm{cm}^{3}$ ), while the increment of true density was only $1.4 \%$ (from 1.406 to $1.425 \mathrm{~g} / \mathrm{cm}^{3}$ ). This demonstrates that the main effect of HPP on the flue-cured tobacco microstructure is the compression of the larger gap between tissues. Nevertheless, its effect on the ultrastructure is substantially weaker. HPP will cause a $46.7 \%$ reduction of the inner pore volume in flue-cured tobacco.
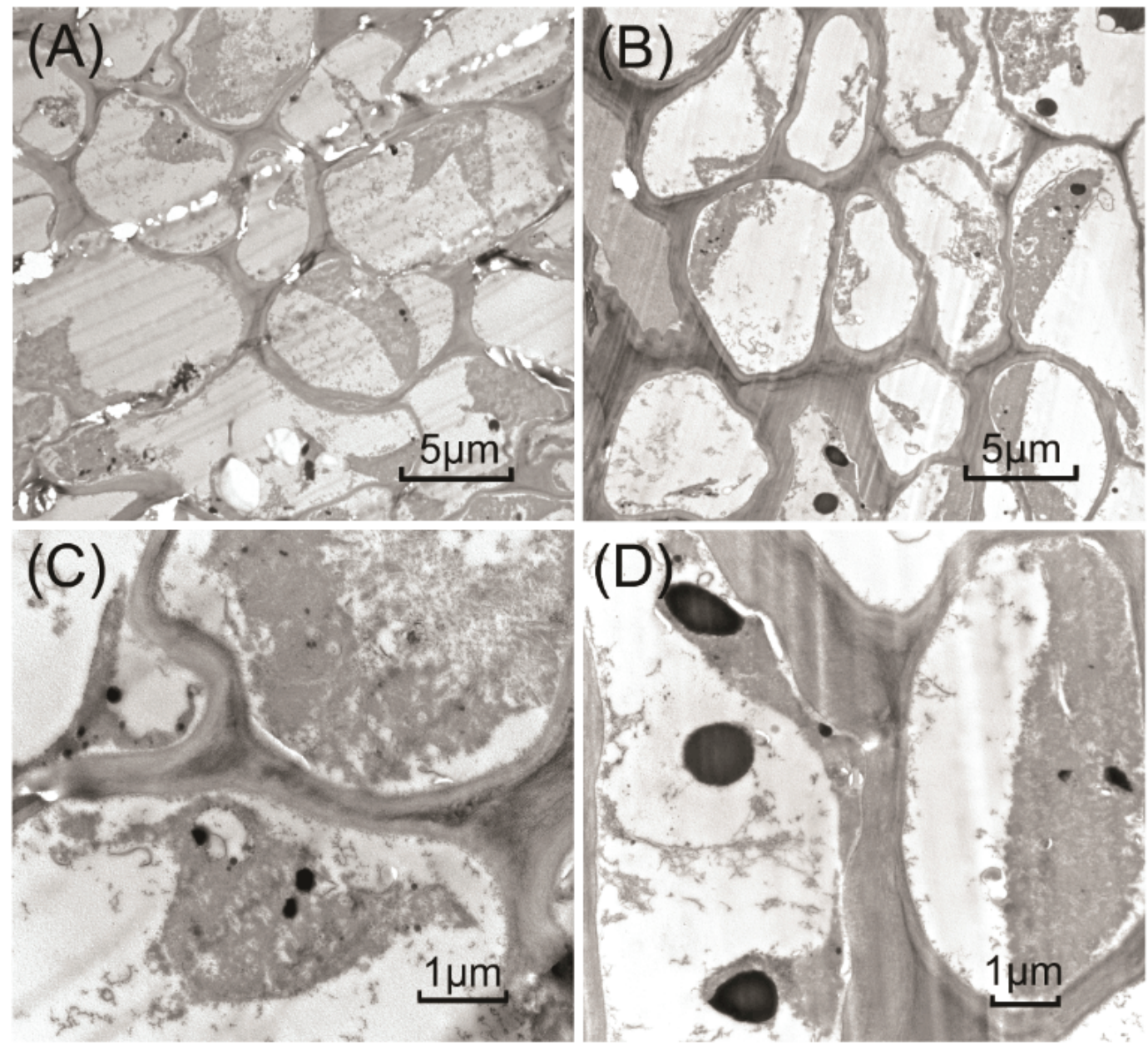

Figure 4. TEM images of the samples (A) CG (6000x); (B) HPP (6000x); (C) CG (25000x); (D) HPP (20000x). 
Table 3. True density, apparent density and inner pore volume of CG and HPP sample.

\begin{tabular}{l|c|c|c}
\hline Sample name & $\begin{array}{c}\text { True } \\
\text { density }\end{array}$ & $\begin{array}{c}\text { Apparent } \\
\text { density }\end{array}$ & $\begin{array}{c}\text { Inner pore } \\
\text { volume }\end{array}$ \\
\hline CG sample & $1.406 \mathrm{~g} / \mathrm{cm}^{3}$ & $0.942 \mathrm{~g} / \mathrm{cm}^{3}$ & $0.353 \mathrm{~cm}^{3} / \mathrm{g}$ \\
HPP sample & $1.425 \mathrm{~g} / \mathrm{cm}^{3}$ & $1.124 \mathrm{~g} / \mathrm{cm}^{3}$ & $0.188 \mathrm{~cm}^{3} / \mathrm{g}$ \\
\hline
\end{tabular}

\section{$T H z-T d S$}

In combination with the above assessments regarding the routine chemical components and density analysis, it is concluded that the main factor of tobacco modification during the HPP treatment is not attributable to a chemical change of the substances. A divergence of chemical components (42) or physical structures (43) may emerge as a remarkable variation in the transmission of a terahertz wave (44). In 2007, FANG et al. (45) studied the phenomenon regarding how a sub-wavelength-sized hole in a metal film affects the transmission of an electric magnetic field.
Abnormal transmission was found to exist in these film samples resulting from surface plasmon polariton-assisted diffraction, and the change was related to samples' morphology characteristics, such as their size, angle and density. Similar technology can serve as a novel tool to investigate microstructures in tobacco samples. Therefore, THz-TDS was applied to study diversities among lamina and powder samples before and after the HPP treatment. Time-domain waveforms of lamina and powder samples before and after the HPP treatment are shown in Figures 5A and $5 \mathrm{C}$. The frequency-resolved transmission spectra were obtained sequentially by fast Fourier transform and are displayed in Figures $5 \mathrm{~B}$ and 5D. It can be seen in Figures 5C and 5D that the transmission rate of HPP-lamina (red line) decreased dramatically compared with CG-lamina (black line). This phenomenon can be interpreted as a result of the HPP treatment. That is, HPP treatment caused the transformation of the microstructure in the tobacco samples and thus affected the propagation of the terahertz wave in the THz-TDS test.
(A)

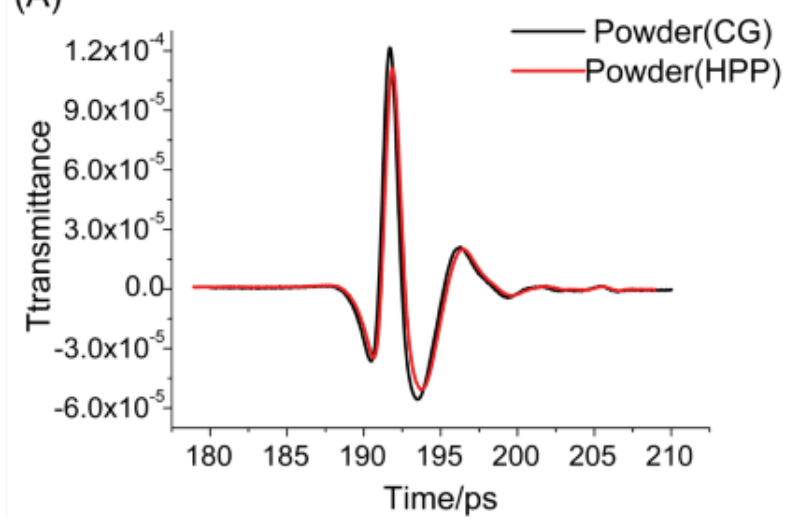

(C)

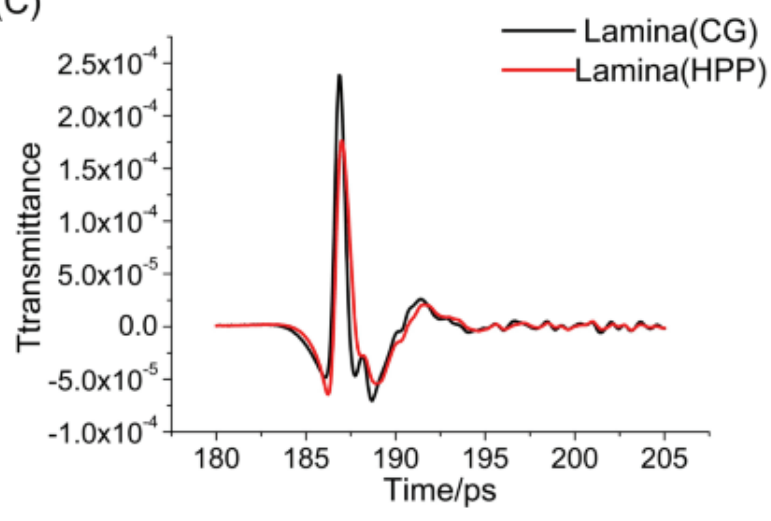

(B)

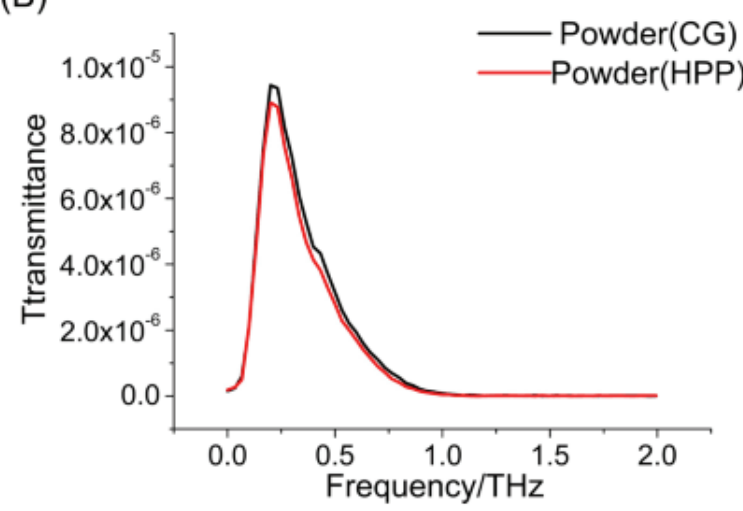

(D)

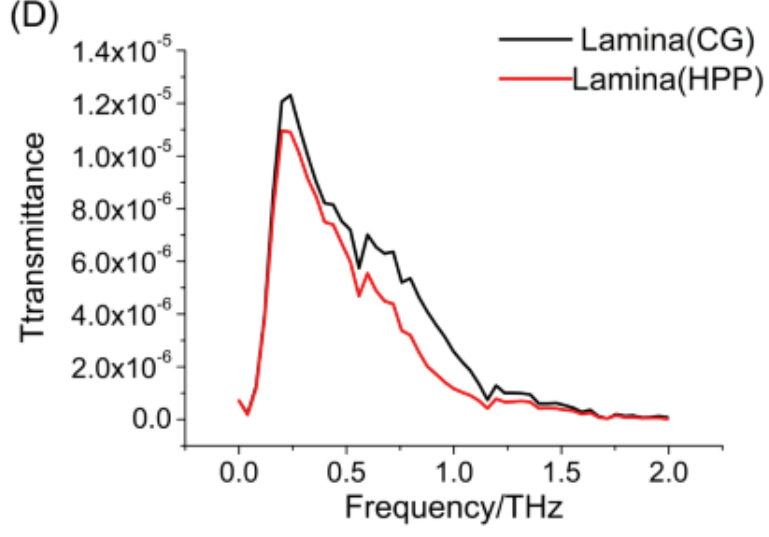

Figure 5. THz-TDS of CG (untreated control group) and HPP (flue-cured tobacco after high pressure processing treatment).

(A) Time-domain pulses of powder samples; (B) Frequency spectra of powder samples;

(C) Time-domain pulses of lamina samples; (D) Frequency spectra of lamina samples. 
This phenomenon did not exist in the two groups of powder samples (Figures 5A and 5B). Allowing for approximately $10 \%$ of randomness due to sample preparation (the upper limit of sample thickness difference), it can be considered that the spectra of HPP-powder are similar to those of CG-powder. This met our expectations as the microstructure in the powder samples had suffered damage to some extent during the preparation process and therefore resulted in a smaller divergence. In addition, some spectral peaks of HPP-lamina at $0.35 \mathrm{THz}, 0.55 \mathrm{THz}$ and $0.76 \mathrm{THz}$ are observed in Figure 5D, while those absorption peaks are not observed in the spectra of the powder samples (Figure $5 \mathrm{~B})$. These peaks are possibly attributed to the interaction between the $\mathrm{THz}$ wave and microstructures, such as multiple reflections and scattering, and reflects that there are more categories of microstructures in the lamina samples. Fractions of these microstructures were changed or destroyed during milling. Most of the remaining parts were smaller structures that had a stronger tolerance to high pressure.

\section{STA detection}

From our previous tests, it can be observed that there are some changes in the microstructure of the flue-cured tobacco after the HPP treatment, which may affect the combustion state. STA is a good tool for studying the combustion state. Figure 6 is the STA result of the lamina and powder samples, including TG, DTG and DSC. The dashed lines in the chart represent the HPP sample, and the black line represents $C G$.

All of the experimental samples began to lose weight slowly at low temperatures. This was probably caused by free water evaporation and the distillation of some volatile matter. A wide and less sharp peak could be seen at $300{ }^{\circ} \mathrm{C}$ on the DTG (dotted line). This was caused by the release of crystal water, which was mainly due to the decomposition of the hemicellulose and cellulose (46).

CZÉGÉNY et al. performed an STA experiment and concluded that the combustion processes started to dominate when the temperature was above $420{ }^{\circ} \mathrm{C}$ (47). The combustion-dominated process shown in our study, as revealed in Figure 5A, is that a rapid weight loss step occurred in the TG (dashed line) between $480{ }^{\circ} \mathrm{C}$ and $570{ }^{\circ} \mathrm{C}$ in both $\mathrm{CG}$ and HPP samples. A large amount of heat was released along with weight loss, and this is reflected in that the DSC (solid line) formed a downward peak. SENNECA et al. confirmed that tobacco's DTG peak temperature decreased with a higher oxygen concentration condition (48). This demonstrates that the pyrolysis of tobacco leaves takes place easily in an oxygen-enriched atmosphere. That is, in the gradual heating of an STA system, the pyrolysis reaction occurs earlier when the amount of oxygen is larger. The inner pore volume of HPP-lamina was significantly reduced and resulted in an increment of the internal diffusion resistance. Therefore, it is more difficult for oxygen to diffuse into the HPP-lamina sample. The amount of oxygen that reached all of the reaction sites inside and outside CG-lamina is larger than that in the HPP-lamina. This phenomenon is reflected in the DSC diagram and is shown by the solid lines in Figure 6A as the exothermic peak of CG-lamina emerged earlier at $505{ }^{\circ} \mathrm{C}$ than the peak of HPP-lamina at $530{ }^{\circ} \mathrm{C}$.

In addition, a result from the research by SENNECA et al. showed that the pyrolysis reaction was more intense and faster when the oxygen concentration was higher (48). The corresponding performance in DSC is a higher exothermic peak height and a smaller full-width at half-maximum (FWHM). The exothermic peak height of CG-lamina was higher than that of HPP-lamina, and the FWHM of the former $\left(62^{\circ} \mathrm{C}\right)$ was smaller than that of the latter $\left(77.5^{\circ} \mathrm{C}\right)$. QI et al. showed that the coal combustion reaction was milder in a system with a low oxygen concentration and resulted in a long reaction time. Therefore, the burnout temperature increased accordingly (49). Similarly, as the contact area of the CG-lamina with oxygen was small, its burnout temperature was higher.

The CG-lamina and HPP-lamina were milled to CG-powder and HPP-powder, and the STA result of this is presented in Figure 6B. It is clear that the CG-powder was nearly the same as the HPP-powder according to both, TG and DSC. This may be evidence of the destruction of the lamina microstructure after milling to a powder.

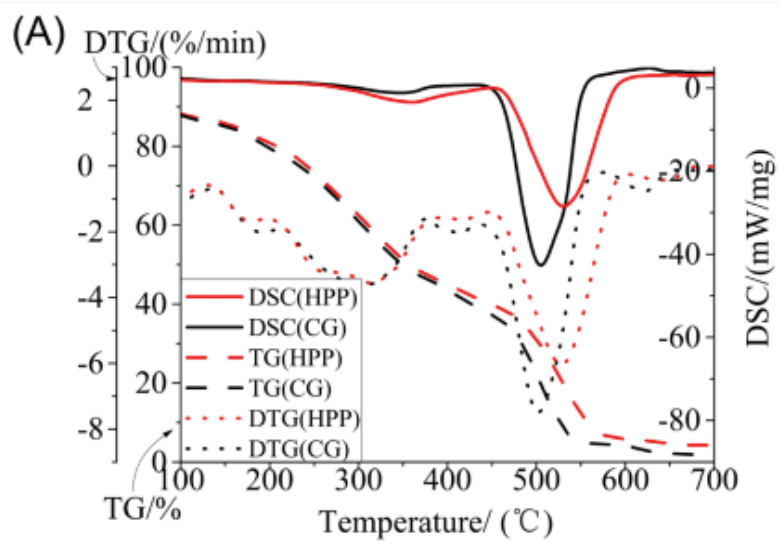

Figure 6. STA curves of the samples (A) lamina and (B) powder.
(B)

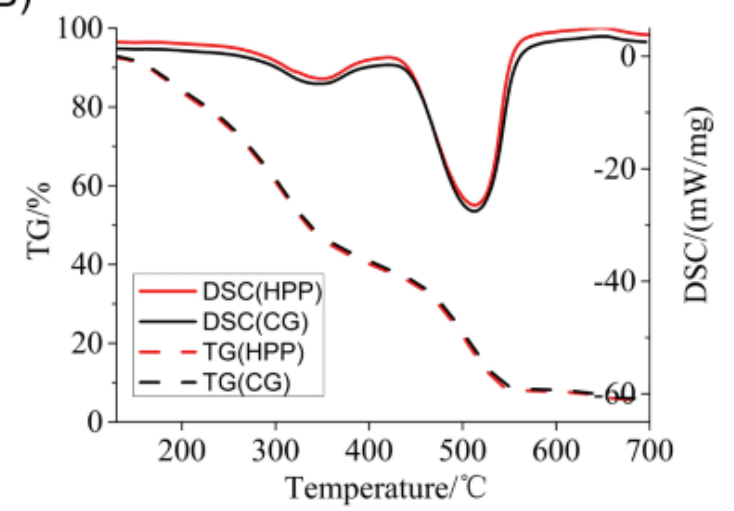




\section{Pyrolysis-GC/MS}

To investigate the characteristics of the product pyrolyzed from the lamina samples and powder samples, a pyrolysis-GC/MS was used. Figure 7 shows the total ion flow diagrams of the lamina samples (the upper part) and powder samples (the lower part). The black lines represent $\mathrm{CG}$, and the dotted lines represent the HPP samples. As seen in Figure 7A, on the whole, the differences in Py-GC/MS between CG-lamina and HPP-lamina were numerous and considerable. Nevertheless, the differences between CG-powder and HPP-powder were very few. For the sake of a clearer display, three sections of the Py-GC/MS graph - the beginning, the middle and the end - were amplified (Figures 7B, 7C and 7D).

The results of the lamina samples can be seen in the upper part of each graph. At retention times of $10.0 \mathrm{~min}$, $12.7 \mathrm{~min}, 17.6 \mathrm{~min}, 19.3 \mathrm{~min}$ and $49.9 \mathrm{~min}$, the relative abundance of CG-lamina was evidently higher than that of

(A)
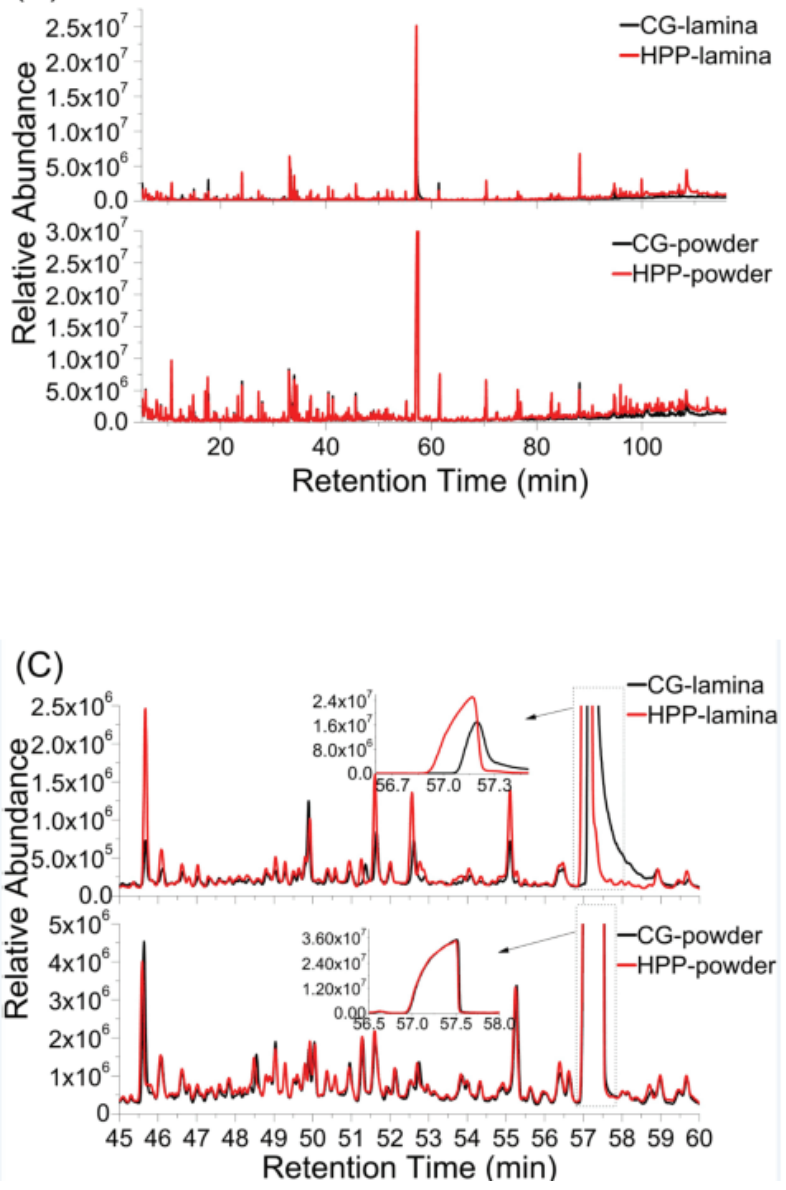

HPP-lamina (the maximum at 12.7 min was more than $300 \%$ ). However, at retention times of $6.4 \mathrm{~min}, 8.6 \mathrm{~min}$, $14.2 \mathrm{~min}, 45.6 \mathrm{~min}, 46.1 \mathrm{~min}, 51.6 \mathrm{~min}, 52.6 \mathrm{~min}$, $55.1 \mathrm{~min}, 57.2 \mathrm{~min}$, and $108.5 \mathrm{~min}$, the relative abundance of CG-lamina was clearly lower than that of HPP-lamina. This shows that the HPP could change the microstructure of the tobacco lamina, which further affected the pyrolysis process; therefore, the gaseous products were very different. For the powder samples (the lower part of each graph) at the same retention time, the differences were small, except at $17.6 \mathrm{~min}, 19.3 \mathrm{~min}$, and $45.6 \mathrm{~min}$ (the maximum was no more than $12.5 \%$ ). This was likely because the microstructure of the lamina was destroyed by the grinding process. As a result, the influence of the structural difference was weakened, which caused the difference of the pyrolysis products to not be very evident.

Meanwhile, we observe a difference between CG-powder and HPP-powder at late retention times in the Py-GC/MS result (101-116 $\mathrm{min})$.
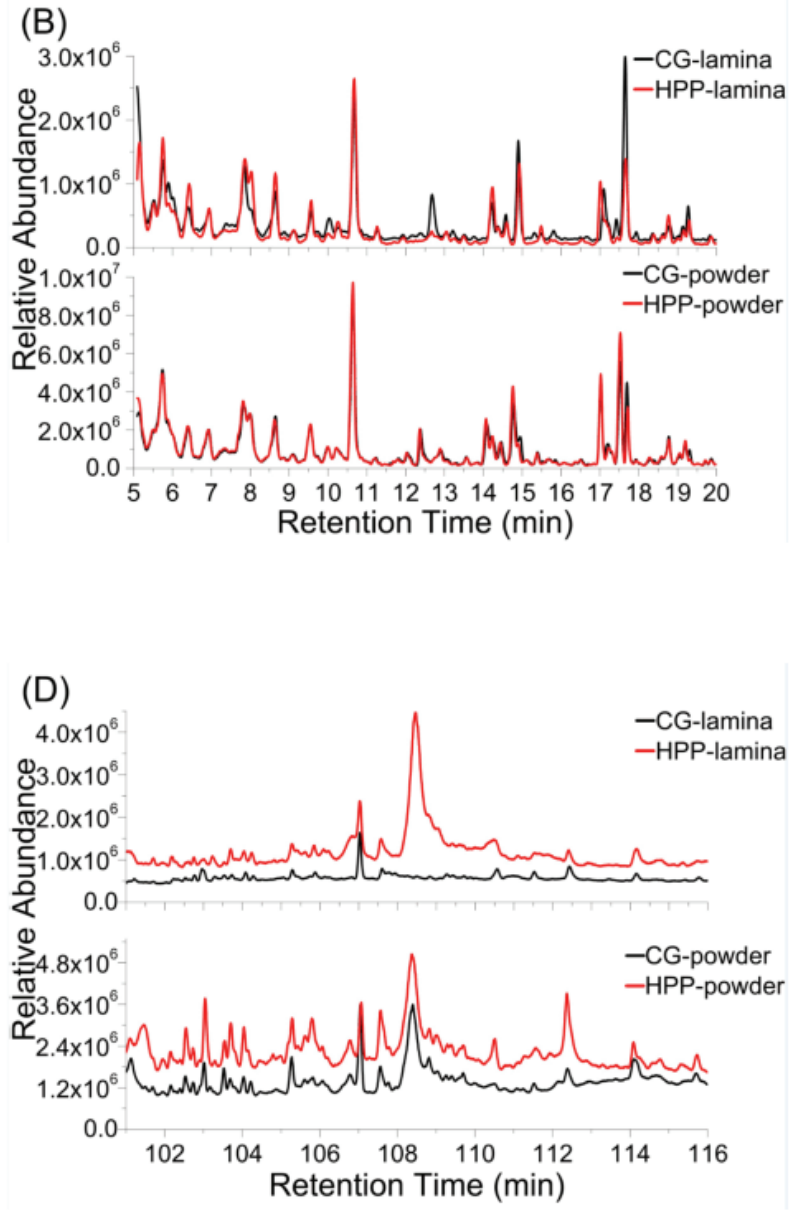

Figure 7. Total ion chromatograms of the pyrolysates from the CG and HPP samples for different retention times. (A) panoramic view; (B) 5-20 min; (C) 45-60 min; (D) 101-116 min. 
The test by MiTsui et al. confirmed that substances eluting at late retention times were obtained by distillation (direct delivery), while the substances eluting at early retention times were not present in tobacco lamina, but were formed by pyrolysis and pyrolysis synthesis during tobacco combustion from less volatile or non-volatile tobacco constituents (50). Similarly, according to BAKER and BISHOP, who pyrolysed n-dotriacontane $\left(\mathrm{a}_{32}\right.$ straight-chain alkane found in tobacco leaves), $54 \%$ of n-dotriacontane transferred intact to the pyrolysate. By contrast, JENKINS et al., who added radiolabeled n-dotriacontane to cigarettes, proposed that $95 \%$ of the n-dotriacontane that transferred to mainstream cigarette smoke was intact. BAKER put forward a possible explanation that in the burning cigarette elution contributed to its intact transfer to smoke (51). Based on a summary of the results of these previous studies, when pyrolysing powder samples, the possible reason for the differences of pyrolysis products at late retention times is that only a portion of the less volatile tobacco constituents transfer to smoke intact. The other part was pyrolysed before exiting the pyrolysis device. This process can be affected by many factors, such as secondary charring (52), catalysis in a polymerization reaction by the char (53), and particle shrinkage, which affect the "tar" content and char content (54). Therefore, even the powder samples will be different for late retention times in the Py-GC/MS results.

\section{CONCLUSIONS}

1. HPP (400 MPa for $10 \mathrm{~min}$ ) had no significant effect on the routine chemical components of flue-cured tobacco, but it did cause a change in the sensory quality.

2. It can be seen from the micromorphology results that HPP caused stoma closure, lamina shrinkage and wrinkling, a decrease of the mesophyll tissue gap, and a narrowing of the internal channel. However, the gap between cells and their cytoskeleton changed little.

3. Compared with CG, the apparent density of the HPP sample increased by $19.3 \%$, while the increment of true density was only $1.4 \%$. This demonstrates that the main effect of HPP on the flue-cured tobacco microstructure is the compression of the larger gap between tissues.

4. In flue-cured tobacco, $46.7 \%$ of the inner pore volume was reduced after the HPP treatment, and this change resulted in a series of effects:

- the internal diffusion resistance to oxygen increased;

- the exothermic peak of CG-lamina emerged earlier at $505{ }^{\circ} \mathrm{C}$ than the peak of HPP-lamina at $530{ }^{\circ} \mathrm{C}$;

- the exothermic peak height was lower, but the burnout temperature and FWHM were both increased.

5. The results for HPP-lamina and CG-lamina differed in THz-TDS, STA and Py-GC/MS, and the difference was significant. However, there was nearly no difference between the powder samples before and after the HPP treatment. These phenomena indicate that milling to a powder could eliminate the structural differences caused by HPP, and it was proven that the change in tobacco caused by HPP only exists in the relatively large microstructure.

\section{ACKNOWLEDGEMENTS}

Mr. Daozhu Dong is acknowledged for assistance in the Pyrolysis-GC/MS analysis. The author (Chao Tan) also thanks Ms. Jihong Cao and Ms. Weiwei Wei for support in some of the experiments.

\section{REFERENCES}

1. Defaye, A.B., D.A. Ledward, D.B. MacDougall, and R.F. Tester: Renaturation of Metmyoglobin Subjected to High Isostatic Pressure; Food Chem. 52 (1995) 19-22. DOI: 10.1016/0308-8146(94)P4175-F

2. Hite, B.H.: The Effect of High Pressure in the Preservation of Milk; West Virginia Agricultural Experimental Station Bulletin 58 (1899) 15-35. Available at: https://archive.org/details/effectofpressure 58hite (accessed August 2017)

3. Evert-Arriagada, K., M.M. Hernández-Herrero, B. Guamis, and A.J. Trujillo: Commercial Application of High-Pressure Processing for Increasing Starter-Free Fresh Cheese Shelf-Life; LWT - Food Sci. Technol. 55 (2014) 498-505. DOI: 10.1016/j.lwt.2013.10.030

4. Maldonado, J.A., D.W. Schaffner, A.M. Cuitiño, and M.V. Karwe: In Situ Studies of Microbial Inactivation During High Pressure Processing; High Press. Res. 36 (2016) 79-89. DOI: 10.1080/08957959.2015.1111887

5. Pietrzak, D., A. Cegiełka, M. Fonberg-Broczek, and M. Ziarno: Effects of High Pressure Treatment on the Quality of Chicken Patties; High Press. Res. 31 (2011) 350-357. DOI: 10.1080/08957959.2011.552503

6. Houška, M., J. Strohalm, K. Kocurová, J. Totušek, D. Lefnerová, J. Tříska, N. Vrchotová, V. Fiedrleová, M. Holasova, D. Gabrovská, and I. Paulíčková: High Pressure and Foods-Fruit/Vegetable Juices; J. Food Eng. 77 (2006) 386-398. DOI: $10.1016 /$ j.jfoodeng.2005.07.003

7. Huang, R., M. Ye, X. Li, L. Ji, M. Karwe, and H. Chen: Evaluation of High Hydrostatic Pressure Inactivation of Human Norovirus on Strawberries, Blueberries, Raspberries and in Their Purees; Int. J. Food Microbiol. 223 (2016) 17-24. DOI: 10.1016/j.ijfoodmicro.2016.02.002

8. Buckow, R., J. Bingham, S. Daglas, S. Lowther, R. Amos-Ritchie, and D. Middleton: High Pressure Inactivation of Selected Avian Viral Pathogens in Chicken Meat Homogenate; Food Control 73 (2017) 215-222. DOI: 10.1016/j.foodcont.2016.08.003

9. Yang, B., Y. Shi, X. Xia, M. Xi, X. Wang, B. Ji, and J. Meng: Inactivation of Foodborne Pathogens in Raw Milk Using High Hydrostatic Pressure; Food Control 28 (2012) 273-278. DOI: 10.1016/j.foodcont.2012.04.030

10. Zhang, Y., X. Liu, Y. Wang, F. Zhao, Z. Sun, and X. Liao: Quality Comparison of Carrot Juices Processed by High-Pressure Processing and High-Temperature Short-Time Processing; Innov. Food Sci. Emerg. Technol. 33 (2016) 135-144. DOI: $10.1016 /$ j.ifset.2015.10.012

11. Zetzl, C., K. Gairola, C. Kirsch, L. Perez-Cantu, and I. Smirnova: High Pressure Processes in Biorefineries; Chem. Ing. Tech. 83 (2011) 1016-1025.

DOI: $10.1002 /$ cite. 201100025 
12. Huang, H.-W., C.-P. Hsu, B.B. Yang, and C.-Y. Wang: Advances in the Extraction of Natural Ingredients by High Pressure Extraction Technology; Trends Food Sci. Technol. 33 (2013) 54-62. DOI: $10.1016 /$ j.tifs.2013.07.001

13. Rastogi, N.K, K.S. Raghavarao, V.M. Balasubramaniam, K. Niranjan, and D. Knorr: Opportunities and Challenges in High Pressure Processing of Foods; Crit. Rev. Food Sci. Nutr. 47 (2007) 69-112.

DOI: $10.1080 / 10408390600626420$

14. Khan N.M., T.H. Mu, H.N. Sun, M. Zhang, and J.W. Chen: Effects of High Hydrostatic Pressure on Secondary Structure and Emulsifying Behavior of Sweet Potato Protein; High Pressure Res. 35 (2015) 189-202. DOI: 10.1080/08957959.2015.1005013

15. Tian, Y., J. Huang, T. Xie, L. Huang, W. Zhuang, Y. Zheng, and B. Zheng: Oenological Characteristics, Amino Acids and Volatile Profiles of Hongqu Rice Wines During Pottery Storage: Effects of High Hydrostatic Pressure Processing; Food Chem. 203 (2016) 456-464.

DOI: 10.1016/j.foodchem.2016.02.116

16. Boluda-Aguilar, M., A. Taboada-Rodríguez, A. LópezGómez, F. Marín-Iniesta, and G.V. Barbosa-Cánovas: Quick Cooking Rice by High Hydrostatic Pressure Processing; LWT Food Sci. Technol. 51 (2013) 196-204. DOI: 10.1016/j.lwt.2012.09.021

17. Wennberg, M. and M. Nyman: On the Possibility of Using High Pressure Treatment to Modify PhysicoChemical Properties of Dietary Fibre in White Cabbage (Brassica Oleracea var. Capitata); Innov. Food Sci. Emerg. Technol. 5 (2004) 171-177.

DOI: $10.1016 /$ j.ifset.2004.02.002

18. Mateos-Aparicio, I., C. Mateos-Peinado, and P. Rupérez: High Hydrostatic Pressure Improves the Functionality of Dietary Fibre in Okara By-Product From Soybean; Innov. Food Sci. Emerg. Technol. 11 (2010) 445-450. DOI: 10.1016/j.ifset.2010.02.003

19. Cappa, C., M. Lucisano, G.V. Barbosa-Cánovas, and M. Mariotti: Physical and Structural Changes Induced by High Pressure on Corn Starch, Rice Flour and Waxy Rice Flour; Food Res. Int. 85 (2016) 95-103.

DOI: 10.1016/j.foodres.2016.04.018

20. Santos, M.D., J.A. Saraiva, M. Teresa, and S.R. Gomes: Pasting of Maize and Rice Starch After High Pressure Processing: Studies Based on an Acoustic Wave Sensor; Sens. Actuator B Chem. 209 (2015) 323-327. DOI: 10.1016/j.snb.2014.11.110

21. Cappa, C., G.V. Barbosa-Cánovas, M. Lucisano, and M. Mariotti: Effect of High Pressure Processing on the Baking Aptitude of Corn Starch and Rice Flour; LWT Food Sci. Technol. 73 (2016) 20-27. DOI: $10.1016 / j .1 w t .2016 .05 .028$

22. Jolie, R.P., S. Christiaens, A. De Roeck, I. Fraeye, K. Houben, S. Van Buggenhout, A.M. Van Loey, and M.E. Hendrickx: Pectin Conversions Under High Pressure: Implications for the Structure-Related Quality Characteristics of Plant-Based Foods; Trends Food Sci. Technol. 24 (2012) 103-118. DOI: $10.1016 /$ j.tifs.2011.11.003

23. Tabilo-Munizaga, G., T.A. Gordon, R. VillalobosCarvajal, L. Moreno-Osorio, F.N. Salazar, M. PérezWon, and S. Acuña: Effects of High Hydrostatic
Pressure (HHP) on the Protein Structure and Thermal Stability of Sauvignon Blanc Wine; Food Chem. 155 (2014) 214-220.

DOI: 10.1016/j.foodchem.2014.01.051

24. Zhang, Z., Y. Yang, P. Zhou, X. Zhang, and J. Wang: Effects of High Pressure Modification on Conformation and Gelation Properties of Myofibrillar Protein; Food Chem. 217 (2017) 678-686.

DOI: $10.1016 /$ j.foodchem.2016.09.040

25. Savadkoohi, S. and S. Kasapis: High Pressure Effects on the Structural Functionality of Condensed GlobularProtein Matrices; Int. J. Biol. Macromol. 88 (2016) 433-442. DOI: 10.1016/j.ijbiomac.2016.04.012

26. Oey, I., M. Lille, A. Van Loey, and M. Hendrickx: Effect of High-Pressure Processing on Colour, Texture and Flavour of Fruit- and Vegetable-Based Food Products: A Review; Trends Food Sci. Technol. 19 (2008) 320-328. DOI: 10.1016/j.tifs.2008.04.001

27. Kim, K.W., Y.-T. Kim, M. Kim, B.-S. Noh, and W.-S. Choi: Effect of High Hydrostatic Pressure (HHP) Treatment on Flavor, Physicochemical Properties and Biological Functionalities of Garlic; LWT Food Sci. Technol. 55 (2014) 347-354. DOI: $10.1016 /$ j.lwt.2013.08.027

28. Liu, S., Q. Xu, X. Li, Y. Wang, J. Zhu, C. Ning, X. Chang, and X. Meng: Effects of High Hydrostatic Pressure on Physicochemical Properties, Enzymes Activity, and Antioxidant Capacities of Anthocyanins Extracts of Wild Lonicera Caerulea Berry; Innov. Food Sci. Emerg. Technol. 36 (2016) 48-58. DOI: $10.1016 /$ j.ifset.2016.06.001

29. Chakraborty, S., N. Kaushik, P.S. Rao, and H.N. Mishra: High-Pressure Inactivation of Enzymes: A Review on its Recent Applications on Fruit Purees and Juices; Compr. Rev. Food Sci. Food Saf. 13 (2014) 578-596. DOI: 10.1111/1541-4337.12071

30. Mao, D., J. Zhang, and G. Yang: Effects of Moisture Content on Flavor Components of Flue-Cured Tobacco Under Ultra High Pressure Treatment; Nongye Gongcheng Xuebao/Transactions of the Chinese Society of Agricultural Engineering; 23 (2007) 211-216.

31. Tobacco Industry Standard of People's Republic of China: Tobacco and Tobacco Products - The Sensory Evaluation Methods; Y.T. 138-1998, Beijing China Standard Press, Beijing, China, 1998.

32. Tobacco Industry Standard of People's Republic of China: Tobacco and Tobacco Products - Determination of Water Soluble Sugars - Continuous Flow Method; Y.T. 159-2002, Beijing China Standard Press, Beijing, China, 2002.

33. Tobacco Industry Standard of People's Republic of China: Tobacco and Tobacco Products - Determination of Total Alkaloids - Continuous Flow Method; Y.T. 160-2002, Beijing China Standard Press, Beijing, China, 2002.

34. Tobacco Industry Standard of People's Republic of China: Tobacco and Tobacco Products - Determination of Total Nitrogen - Continuous Flow Method; Y.T. 161-2002, Beijing China Standard Press, Beijing, China, 2002.

35. Tobacco Industry Standard of People's Republic of China: Determination of Apparent Density, True 
Density and Inner Pore Volume of Cut Tobacco; Y.T. 473-2013, Beijing China Standand Press, Beijing, China, 2013.

36. Hendrickx, M., L. Ludikhuyze, I. Van den Broeck, and C. Weemaes: Effects of High Pressure on Enzymes Related to Food Quality; Trends Food Sci. Technol. 9 (1998) 197-203.

37. Schroeder, J.I., G.J. Allen, V. Hugouvieux, J.M. Kwak, and D. Waner: Guard Cell Signal Transduction; Ann. Rev. Plant Physiol. Plant Mol. Biol. 52 (2001) 627-658. DOI: 10.1146/annurev.arplant.52.1.627

38. Melotto, M., W. Underwood, J. Koczan, K. Nomura, and S.Y. He: Plant Stomata Function in Innate Immunity Against Bacterial Invasion; Cell 126 (2006) 969-980. DOI: 10.1016/j.cell.2006.06.054

39. Fan, L.M., Z. Zhao, and S.M. Assmann: Guard Cells: A Dynamic Signaling Model; Curr. Opin. Plant Biol. 7 (2004) 537-546. DOI: 10.1016/j.pbi.2004.07.009

40. Brodersen, C.R. and A.B. Roddy: New Frontiers in the Three-Dimensional Visualization of Plant Structure and Function; Am. J. Bot. 103 (2016) 184-188. DOI: $10.3732 / a j b .1500532$

41. Kuroki, S., S. Oshita, I. Sotome, Y. Kawagoe, and Y. Seo: Visualization of 3-D Network of Gas-Filled Intercellular Spaces in Cucumber Fruit after Harvest; Postharvest Biol. Technol. 33 (2004) 255-262. DOI: 10.1016/j.postharvbio.2004.04.002

42. Bigourd, D., A. Cuisset, F. Hindle, S. Matton, R. Bocquet, G. Mouret, F. Cazier, D. Dewaele, and H. Nouali: Multiple Component Analysis of Cigarette Smoke Using THz Spectroscopy, Comparison with Standard Chemical Analytical Methods; Appl. Phys. B 86 (2007) 579-586. DOI: 10.1007/s00340-006-2495-4

43. Png, G.M., R.J. Falconer, B.M. Fischer, H.A. Zakaria, S.P. Mickan, A.P. Middelberg, and D. Abbott: Terahertz Spectroscopic Differentiation of Microstructures in Protein Gels; Opt. Express 17 (2009) 13102-13115. DOI: 10.1364/OE.17.013102

44. Su, T.-F., X.-F. Jia, G.-Z. Zhao, P. Han, Y.-J. Wang, Y. Li, B. Zhou, C.-P. Song, J.-F. Chang, and C.R. Gong: Characterization of Original and Expanded Leaf-Roots of Tobacco by Terahertz Spectroscopy and X-Ray Microanalysis; Mater. Lett. 62 (2008) 277-2782.

DOI: 10.1016/j.matlet.2008.01.043

45. Fang, X., H.X. Wei, M. Kamran, J.Y. Ma, H.Y. Zhao, X.F. Han, and Qiu: Surface Plasmon Polaritons Assisted Diffraction in Metal Films with Subwavelength Hole Array; J. Phys. Chem. Solids 69 (2008) 3093-3095. DOI: 10.1016/j.jpcs.2008.06.099

46. Várhegyi, G., Z. Czégény, E. Jakab, K. McAdam, and C. Liu: Tobacco Pyrolysis. Kinetic Evaluation of Thermogravimetric-Mass Spectrometric Experiments; J. Anal. Appl. Pyrolysis 86 (2009) 310-322. DOI: $10.1016 /$ j.jaap.2009.08.008
47. Czégény, Z., M. Blazsó, G. Várhegyi, E. Jakab, C. Liu, and L. Nappi: Formation of Selected Toxicants from Tobacco under Different Pyrolysis Conditions; J. Anal. Appl. Pyrolysis 85 (2009) 47-53. DOI: $10.1016 /$ j.jaap.2008.10.001

48. Senneca, O., R. Chirone, P. Salatino, and L. Nappi: Patterns and Kinetics of Pyrolysis of Tobacco under Inert and Oxidative Conditions; J. Anal. Appl. Pyrolysis 79 (2007) 227-233. DOI: 10.1016/j.jaap.2006.12.011

49. Qi, X., Q. Li, H. Zhang, and H. Xin: Thermodynamic Characteristics of Coal Reaction Under Low Oxygen Concentration Conditions; J. Energy Inst. 90 (2017) 544-555. DOI: 10.1016/j.joei.2016.05.007

50. Mitsui, K., F. David, E. Dumont, N. Ochiai, H. Tamura, and P. Sandra: LC Fractionation Followed by Pyrolysis GC-MS for the In-Depth Study of Aroma Compounds Formed During Tobacco Combustion; J. Anal. Appl. Pyrolysis 116 (2015) 68-74.

DOI: $10.1016 /$ j.jaap.2015.10.004

51. Baker, R.R. and L.J. Bishop: The Pyrolysis of Tobacco Ingredients; J. Anal. Appl. Pyrolysis 71 (2004) 223-311. DOI: 10.1016/S0165-2370(03)00090-1

52. Anca-Couce, A.: Reaction Mechanisms and MultiScale Modelling of Lignocellulosic Biomass Pyrolysis; Prog. Energy Combust. Sci. 53 (2016) 41-79. DOI: 10.1016/j.pecs.2015.10.002

53. Tripathi, M., J.N. Sahu, and P. Ganesan: Effect of Process Parameters on Production of Biochar from Biomass Waste Through Pyrolysis: A Review; Renew. Sust. Energy Rev. 55 (2016) 467-481. DOI: $10.1016 /$ j.rser.2015.10.122

54. Sharma, A., V. Pareek, and D. Zhang: Biomass Pyrolysis - A Review of Modelling, Process Parameters and Catalytic Studies; Renew. Sust. Energy Rev. 50 (2015) 1081-1096. DOI: 10.1016/j.rser.2015.04.193

Corresponding author:

Yong Jin, Ph.D.

China Tobacco Hunan Industrial Co., Ltd

Changsha, Hunan

China

E-Mail: jiny1227@hngytobacco.com 
Appendix. Abbreviations and definition of terms.

\begin{tabular}{ll}
\hline Term & Definition \\
\hline CG & Control group \\
CT & Computed tomography \\
DSC & Differential scanning calorimetry \\
DTG & Differential thermal gravimetry \\
FWHM & Full-width at half-maximum \\
HPP & High-pressure processing \\
Micro-CT & Microtomography \\
MPa & Megapascal \\
POD & Peroxidase \\
PPO & Polyphenol oxidase \\
Py-GC/MS & Pyrolysis gas chromatography/mass spectrometry \\
SEM & Scanning electron microscopy \\
STA & Simultaneous thermal analysis \\
TEM & Transmission electron microscopy \\
TG & Thermogravimetry \\
THz-TdS & Terahertz time-domain spectroscopy analysis \\
\hline
\end{tabular}

